\title{
Influencing Factors for IT Software Project Failures in Developing Countries - A Critical Literature Survey
}

\author{
Shouki A. Ebad* \\ Faculty of Computing and IT, Northern Border University, Saudi Arabia. \\ * Corresponding author. Tel.: +96614 6615454; email: shouki.abbad@nbu.edu.sa \\ Manuscript submitted July 27, 2016; accepted October 18, 2016. \\ doi: 10.17706/jsw.11.11.1145-1153
}

\begin{abstract}
Software projects still suffer from high failure rates, especially in developing countries. However, no one evaluated the current studies that were conducted in the context of Saudi Arabia (SA), a developing country. We try to fill this gap using a property-based critical literature survey of existing studies. The findings suggest that management/organization factors including lack of top management support, organizational culture, business process reengineering, lack of training, and unavailability of project management office are main factors that influence software project failures in SA. However, technical and financial factors are secondary; this might be due to the extensive government subsidization for IT. Our analysis can assist software project managers in SA, and it may apply to other developing countries in the Middle East.
\end{abstract}

Key words: software project management, software engineering, success, failure, developing countries.

\section{Introduction}

Although several researchers have been identifying the factors behind the high rate of failures for software projects, the factors are still divergent and complex [1][2]. In the UK, substantial failures in software development efforts for the London Ambulance System resulted in huge costs [3]. In the US, Hewlett-Packard (HP) lost USD 160 million in 2004 from development system failures [4]. In 2014, Toyota announced a recall of its Prius vehicles to fix a software glitch that could cause its cars to stall [5]. The majority of the Saudi Arabia (SA) software systems in the hospital and healthcare sectors have been classified as failed projects [6]. The problem is then commonplace throughout the world. Meanwhile, there is little agreement concerning the global failure factors [1], [2], [7]. Moreover, while it is well-known and widely used, the term "failure" is difficult to define [1]. SA has one of the highest gross national incomes per capita. Also, it is one of the highest per capita expenditures on IT. Despite the rich body of research on IT failures in SA, failed projects continue to occur. The objective of this paper is to discuss and debate the reasons for software project failures in Saudi organizations and to provide some directions for future research. To this end, we used a property-based critical literature survey of current studies related software project failures in SA. Although several studies have been conducted in SA, no formal study has hitherto been conducted to evaluate the studies already available. This paper attempts to fill this gap. There have several attempts to address the problem throughout the world, in the US, UK, Australia, Japan, Malaysia, and Jordan [5], [8]-[13]. This study focuses on the effort that has been put to address the issue in SA.

\section{A Property-Based Critical Survey}


A critical literature survey is far more than a simple summary of the literature; it is an analysis and evaluation of the reviewed studies. Therefore, it requires an understanding of the material and the ability to analyze and classify that material using appropriate criteria [14]. Throughout the process of surveying existing works, we discovered a set of properties that can be used to classify and compare such studies. This set of properties is expected to help guide researchers trying to extract the important factors that lead to software project failures. Our proposed properties are discussed below.

- Objective: Understanding the objectives is critical for evaluating factors that have an influence on failure. This attribute states whether the study focus was "failure," "success," or both.

- Definability: As mentioned in Section 1, such definition of "failure" is not typically clearly stated. Therefore, this property represents whether the study author clearly defined the term failure.

- Measurability: DeMarco asserts that "You cannot control what you cannot measure"[15]. The measurability property determines what metrics, if any, were used to measure failure.

- Perspective: Failure can be viewed from the perspective of software developers, project managers (PM), top management, users, and clients vs. suppliers.

- Factors List: This property describes the resulting factors that influence failure (or success).

- Methodology: It specifies the investigation strategy: survey, case study, or experiment [16].

- Environment: It determines whether the study conduct in academia, industry, or a mix of the two.

- Practicality: This property determines whether the study concentrates on specific IT software project types; for example, knowledge systems and enterprise resource planning (ERP).

- Sector: This property determines the business sector and type of firm on which the study was conducted. The sectors include public, private, and non-profit sectors, while the firm type specifies the type of firm studied, such as education, military, or e-government.

\section{Evaluation against Properties}

Based on the properties discussed in the previous section, we evaluated the works that were conducted in (2011-2015) in a SA context. Tables 1 through 12 discuss twelve works in chronological order.

Table 1. Study of (Aldayel et al. 2011) [17]

\begin{tabular}{|c|c|}
\hline Prop. & Comments \\
\hline Obj. & $\begin{array}{l}\text { Success-to identify the CSFs of ERP systems } \\
\text { through exploring the literature on ERP } \\
\text { implementation }\end{array}$ \\
\hline Def. & $\begin{array}{l}\text { The used CSFs are those proposed by [18][19] } \\
\text { were used }\end{array}$ \\
\hline Meas. & No mention \\
\hline Persp. & Technical perspective and user perspectives \\
\hline $\begin{array}{c}\text { Factor } \\
\mathrm{s}\end{array}$ & $\begin{array}{l}\text { PM, ERP selection, and the training offered to } \\
\text { the end users }\end{array}$ \\
\hline $\begin{array}{c}\text { Methg } \\
\text { y. }\end{array}$ & $\begin{array}{l}\text { Two questionnaires were designed, (1) for staff } \\
\text { working on Madar to find the CSFs from a } \\
\text { technical prospective; Likert Scale was used, } \\
\text { and (2) for the end-users to find the user } \\
\text { satisfaction; Guttman scale and Rating scale } \\
\text { were used. } 130 \text { questionnaire requests were } \\
\text { distributed manually and via email; response } \\
\text { rate was 29\%. SPSS was used to test results. }\end{array}$ \\
\hline Env. & Academic \\
\hline Pract. & $\begin{array}{c}\text { Madar system, an ERP system developed at } \\
\text { King Saud University }\end{array}$ \\
\hline
\end{tabular}

\begin{tabular}{|l|l|}
\hline Sector & Public - Educational institutes \\
\hline
\end{tabular}

Table 2. Study of (Al-turki 2011) [20]

\begin{tabular}{|c|c|}
\hline Prop. & Comments \\
\hline Obj. & $\begin{array}{c}\text { Success- to identify best practices and } \\
\text { factors affecting successful } \\
\text { implementations of ERP systems. }\end{array}$ \\
\hline Def. & No mention \\
\hline Meas. & $\begin{array}{c}\text { It was used a category evaluation } \\
\text { system; complete success; partial } \\
\text { success; and complete failure }\end{array}$ \\
\hline Persp. & Implementers and vendors \\
\hline Factors & $\begin{array}{c}\text { Human related factors such as } \\
\text { leadership, change management and } \\
\text { training. The results suggest having } \\
\text { business leadership rather than IT } \\
\text { leadership accompanied by extensive } \\
\text { change management and training } \\
\text { programs }\end{array}$ \\
\hline Methgy. & $\begin{array}{c}\text { A questionnaire distributed over } \\
\text { different types of Saudi organizations } \\
\text { (local, foreign, multinational, }\end{array}$ \\
\hline
\end{tabular}




\begin{tabular}{|c|c|}
\hline & $\begin{array}{c}\text { conglomerates, SMEs). 93 } \\
\text { organizations were responded. }\end{array}$ \\
\hline Env. & Academic \\
\hline Pract. & ERP \\
\hline Sector & Public and private \\
\hline
\end{tabular}

\begin{tabular}{|c|c|}
\hline Env. & Academic (2) and industry (1) \\
\hline Pract. & IT projects \\
\hline Sector & Public sector (64\%) and private sector (36\%) \\
\hline
\end{tabular}

Table 5. Study of (Sharief 2012) [22]

Table 3. Study of (Abouzahra 2011) [6]

\begin{tabular}{|c|c|}
\hline Pr & Comments \\
\hline $\begin{array}{c}\text { Ob } \\
\text { j. }\end{array}$ & Failure- to study healthcare software project \\
causes of failure compared to other types of project. \\
\hline $\begin{array}{c}\text { De } \\
\text { f. }\end{array}$ & $\begin{array}{c}\text { Failure is defined as failing to meet the objectives in } \\
\text { terms of project scope, schedule, or cost [9]. }\end{array}$ \\
\hline Me & No mention \\
as. & Managerial \\
\hline Pe & \\
rs & \\
p. & Fa \\
Fa & Unclear scope, undefined risks, undefined \\
rs & stakeholders, and communication. \\
\hline Me & A 4-year study of the healthcare software projects in \\
th & 6 hospitals in (2007-2011). The author was able to \\
gy. & study those projects (29 projects) closely and in \\
\hline En & person as a PM consultant for the hospitals. \\
v. & Industry \\
\hline Pr & \\
act & HIS (healthcare information systems) \\
. & \\
\hline Se & \\
cto & \\
r & Public \\
\hline
\end{tabular}

\begin{tabular}{|c|c|}
\hline Prop. & Comments \\
\hline Obj. & $\begin{array}{c}\text { Success \& failure- to assess the key challenges } \\
\text { of the e-government implementation }\end{array}$ \\
\hline Def. & No mention \\
\hline Meas. & No mention \\
\hline Persp. & $\begin{array}{c}\text { From 11 challenges, the greatest importance } \\
\text { factor was citizen trust in e-government } \\
\text { challenges. Followed with legal and regulatory } \\
\text { challenges; and information and data challenges }\end{array}$ \\
\hline Methgy & $\begin{array}{c}\text { The selected firms had already implemented the } \\
\text { e-government projects. } \\
\text { The questionnaire was handed to 50 experts } \\
\text { (varying in sex, education, and experience years) } \\
\text { working on different e-government projects }\end{array}$ \\
\hline Env. & Academic \\
\hline Pract. & e-government projects \\
\hline Sector & Public \\
\hline
\end{tabular}

Table 6. Study of (Alfarraj et al. 2013) [23]

\begin{tabular}{|c|c|}
\hline Prop. & Comments \\
\hline Obj. & $\begin{array}{l}\text { Success \& failure- to identify the factors } \\
\text { influencing the implementation and } \\
\text { development of e-government in SA }\end{array}$ \\
\hline Def. & No mention \\
\hline Meas. & No mention \\
\hline Persp. & Cooperation \& collaboration \\
\hline Factors & $\begin{array}{l}\text { Cooperation \& collaboration factors which } \\
\text { include (1) cooperation of government } \\
\text { sectors with Yesser program1, (2) } \\
\text { cooperation of government sectors with e- } \\
\text { services developers to developer electronic } \\
\text { services, (3) cooperation of government } \\
\text { sectors with each other to transfer the } \\
\text { required data for developing electronic } \\
\text { services, (4) cooperation of the top } \\
\text { managements with their departments within } \\
\text { organizations to facilitate the implementation } \\
\text { and development of e-government, (5) } \\
\text { cooperation of financial departments with } \\
\text { other internal departments within } \\
\text { government sectors to facilitate funding the } \\
\text { projects of IT, and (6) the cooperation of } \\
\text { Yesser program and government sectors with } \\
\text { researchers and research centers to conduct } \\
\text { studies about e-government implementation } \\
\text { and its issues }\end{array}$ \\
\hline $\begin{array}{c}\text { Methgy } \\
\text {. }\end{array}$ & $\begin{array}{l}21 \text { unstructured qualitative interviews were } \\
\text { conducted with different groups of }\end{array}$ \\
\hline
\end{tabular}

${ }^{1}$ Yesser program is an umbrella for all e-government activities, procedures, legislations and other related issues and acts as the government's controller. (www.yesser.gov.sa) 


\begin{tabular}{|c|c|}
\hline & $\begin{array}{c}\text { participants involved in the development and } \\
\text { implementation. Grounded theory techniques } \\
\text { were employed to analyze data. }\end{array}$ \\
\hline Env. & Academic \\
\hline Pract. & e-government \\
\hline Sector & Public \\
\hline
\end{tabular}

Table 7. Study of (Almajed and Mayhew 2013) [24]

\begin{tabular}{|c|c|}
\hline Prop. & Comments \\
\hline Obj. & $\begin{array}{l}\text { Success- to identify the success factors from } \\
\text { chief information officers' (CIOs) perceptive. }\end{array}$ \\
\hline Def. & No mention \\
\hline Meas. & No mention \\
\hline Persp. & $\mathrm{CIO}$ \\
\hline Factors & $\begin{array}{l}\text { Organizational: top management support and } \\
\text { commitment strategic planning, project } \\
\text { management office (PMO), conflict of interest, } \\
\text { top management stability. } \\
\text { Process: management of (project, change, } \\
\text { stakeholders, risk, supplier, communication, } \\
\text { and knowledge) plus business process } \\
\text { reengineering (BPR }{ }^{2} \text { ). } \\
\text { Resource management: competency, } \\
\text { infrastructure, training \& education, reward \& } \\
\text { recognition. }\end{array}$ \\
\hline Methgy & $\begin{array}{l}\text { A semi-structure interview. Invitations were } \\
\text { sent to } 20 \text { CIOs in the field who had at least } \\
\text { five years' experience of IT management; only } \\
10 \text { agreed to participate. The researchers } \\
\text { conducted the interviews using the VoIP such } \\
\text { as Skype. }\end{array}$ \\
\hline Env. & Academic \\
\hline Pract. & IT software projects \\
\hline Sector & Public \\
\hline
\end{tabular}

Table 8: Study of (Altahtooh and Emsley 2013) [26]

\begin{tabular}{|c|c|}
\hline Pr & Comments \\
\hline bj. & Success \& failure- to discover the role of a PMO on \\
success and failure.
\end{tabular}

\footnotetext{
${ }^{2}$ BPR is the analysis and redesign of workflow within and between
} enterprises [25]

\begin{tabular}{|c|c|}
\hline & $\begin{array}{c}\text { Yanbu and Madinah). SPSS package was used in data } \\
\text { analysis. }\end{array}$ \\
\hline En & Academic \\
v. & IT projects \\
\hline $\mathrm{Pr}$ & \\
ac & \\
t. & Se \\
ct & Public (42\%) and private (58\%) \\
or & \\
\hline
\end{tabular}

Table 9. Study of (Saleh et al. 2013) [27]

\begin{tabular}{|c|c|}
\hline Prop. & Comments \\
\hline Obj. & $\begin{array}{c}\text { Success - to fill the gap between western } \\
\text { countries and middle eastern countries } \\
\text { especially SA in conducting studies about CSFs } \\
\text { of ERP implementation }\end{array}$ \\
\hline Def. & No mention \\
\hline Meas. & No mention \\
\hline Persp. & Organizational \\
\hline Factors & $\begin{array}{c}\text { Vendor \& user support, consultant competence, } \\
\text { and BPR. Top management was not significant }\end{array}$ \\
\hline Methgy & $\begin{array}{c}\text { A sample size of 150 organizations varying } \\
\text { sizes, activities, ownership were chosen in this } \\
\text { study. Response rate was 49.3\% }\end{array}$ \\
\hline Env. & Academic \\
\hline Pract. & ERP \\
\hline Sector & Public and private \\
\hline
\end{tabular}

Table 10. Study of (Alateyah et al. 2013) [28]

\begin{tabular}{|c|c|}
\hline Prop. & Comments \\
\hline Obj. & $\begin{array}{l}\text { Success \& Failure- to identify the challenges } \\
\text { that face adoption of e-government in SA }\end{array}$ \\
\hline Def. & No mention \\
\hline Meas. & No mention \\
\hline Persp. & Stakeholders, culture, and technical \\
\hline Factors & $\begin{array}{c}\text { Quality of service, diffusion of innovation, } \\
\text { computer \& information literacy, culture, lack of } \\
\text { awareness, technical infrastructure, website } \\
\text { design, security, privacy, and trust. }\end{array}$ \\
\hline $\begin{array}{c}\text { Methgy } \\
.\end{array}$ & $\begin{array}{l}\text { (1) Citizens' questionnaire had } 15 \text { closed-ended } \\
\text { questions distributed online (2) Government } \\
\text { employees' questionnaire had } 23 \text { closed-ended } \\
\text { questions handed in person (3) Experts' } \\
\text { interview had } 29 \text { closed-ended questions which } \\
\text { interviewed in person, and the results were } \\
\text { tested using SPSS }\end{array}$ \\
\hline Env. & Academic \\
\hline Pract. & e-government \\
\hline Sector & Public \\
\hline
\end{tabular}

Table 11. Study of (Almajed and Mayhew 2014) [13]

\begin{tabular}{|c|c|}
\hline Prop. & Comments \\
\hline Obj. & $\begin{array}{c}\text { Success- to compare the CSFs for software } \\
\text { projects between SA and Malaysia }\end{array}$ \\
\hline Def. & No mention \\
\hline Meas. & No mention \\
\hline
\end{tabular}




\begin{tabular}{|c|c|}
\hline Persp. & CIO \\
\hline Factors & $\begin{array}{c}\text { In both countries, success was influenced by } \\
\text { PM; and not influenced by competency. In SA, } \\
\text { success was influenced by top management } \\
\text { support while it is influenced by } \\
\text { communication management in Malaysia. In SA, } \\
\text { organizational culture moderates the } \\
\text { relationships among top management support, } \\
\text { PM, and IT project success. In Malaysian, } \\
\text { organizational culture moderates the } \\
\text { relationships among communication } \\
\text { management, PM, and IT project success. }\end{array}$ \\
\hline Methgy. & $\begin{array}{c}\text { A survey questionnaire was sent to 140 CIOs } \\
\text { (varying in age and education) directly or } \\
\text { indirectly using email and LinkedIn social } \\
\text { network. The response which was 52\%. SPSS } \\
\text { and SmartPLS packages were used for analysis }\end{array}$ \\
\hline Env. & Academic \\
\hline Pract. & IT projects \\
\hline Sector & Public \\
\hline
\end{tabular}

\begin{tabular}{|c|c|}
\hline Def. & could lead to failure \\
\hline Meas. & $\begin{array}{c}\text { From the participants responses, a failed project } \\
\text { is a result (product or service) of unprofessional } \\
\text { management practices (related to plan and } \\
\text { process) employed by the project team (people) }\end{array}$ \\
$\begin{array}{c}\text { IT project failure may be linked to the following } \\
\text { elements in PM knowledge: process, plan, } \\
\text { people and product (3Ps = P); the relationship } \\
\text { between these elements of 3Ps = P could be } \\
\text { shown as follows: IT project = [(Plan * Process) / } \\
\text { People] = Product }\end{array}$ \\
\hline Persp. & $\begin{array}{c}\text { Managerial (72\% of factors), technical and } \\
\text { financial (28\% of factors) }\end{array}$ \\
\hline Factors & $\begin{array}{c}\text { Factors were classified into four groups: P1 that } \\
\text { happen in the planning stage - such as unclear } \\
\text { objectives, P2 that happen in the execution stage } \\
\text { - such as poor communication, P3 that are } \\
\text { relating to the persons involved in a project, } \\
\text { such as conflict among users, and P4 that } \\
\text { happen after delivering a project. As a result, } \\
\text { very high risk factors can fall in (P2) then (P1) }\end{array}$ \\
\hline
\end{tabular}

Table 12. Study of (Altahtooh and Emsley 2015) [29]

\begin{tabular}{|c|c|}
\hline Prop. & Comments \\
\hline Obj. & Failure-to identify IT project risk factors that \\
\hline Methgy & $\begin{array}{c}\text { Semi-structured in-depth interviews using the } \\
\text { critical incident technique -CIT (Woolsey 1986). } \\
\text { The sample size of CIT was 15 IT project } \\
\text { managers who were interviewed in SA, } \\
\text { discussing about 30 projects }\end{array}$ \\
\hline Env. & Academic \\
\hline
\end{tabular}

\begin{tabular}{|c|c|}
\hline Pract. & IT projects \\
\hline Sector & Public and private \\
\hline
\end{tabular}

\section{Observations}

Based on these analyses, our observations associated with the influencing factors as follows:

- Most studies did not truly define the terms failure. Each researcher should have provided the questionnaire participants with specific definitions of failure. Because this did not happen, answers to the questionnaire questions are debatable because answers were supplied based on the personal definition of the terms failure of each participant, and their definitions may differ from that of the interviewers or researchers. This issue, as we explained in section 1, is not related solely to SA studies but applies equally as well to studies worldwide. We think dealing with failure as if it were white and black is unfair. It is difficult to consider an entire project as a failure simply because cost violations or scheduling failures occurred. The same is true of a successful project: a project cannot be considered a success solely based on customer satisfaction without considering the full scope or the objectives of the project. According to Schwalbe [30], there are three criteria that indicate when a project is not success: (1) when it has not met the triple constraints of scope, cost, and schedule, (2) when the customer or sponsor is not satisfied, and (3) when the results do not meet the main objectives. Some studies defined failure and success using grading scales: complete success, partial success, and complete failure [20].

- Although the failure issue occurs primarily in industry as opposed to academia, almost all the reviewed studies were conducted by academics, which is indicative of a gap between industry and academia in SA. However, working with real-world cases or systems from the industry or market is a common problem in much IT research. Another observation is about the existence of research barriers in the private sector compared with the public sector. In SA, no study was conducted in the non-profit sector, and the number of studies conducted in the private sector was small compared to those conducted in the public sector.

- We classified the factors affecting software project failures in SA into three main perspectives: technical, end-user, and management/organization. Figure 1 shows various influencing factors from those three perspectives. Although PM is part of the managerial/organizational perspective, we separated it because it has become a separate, independent branch. 


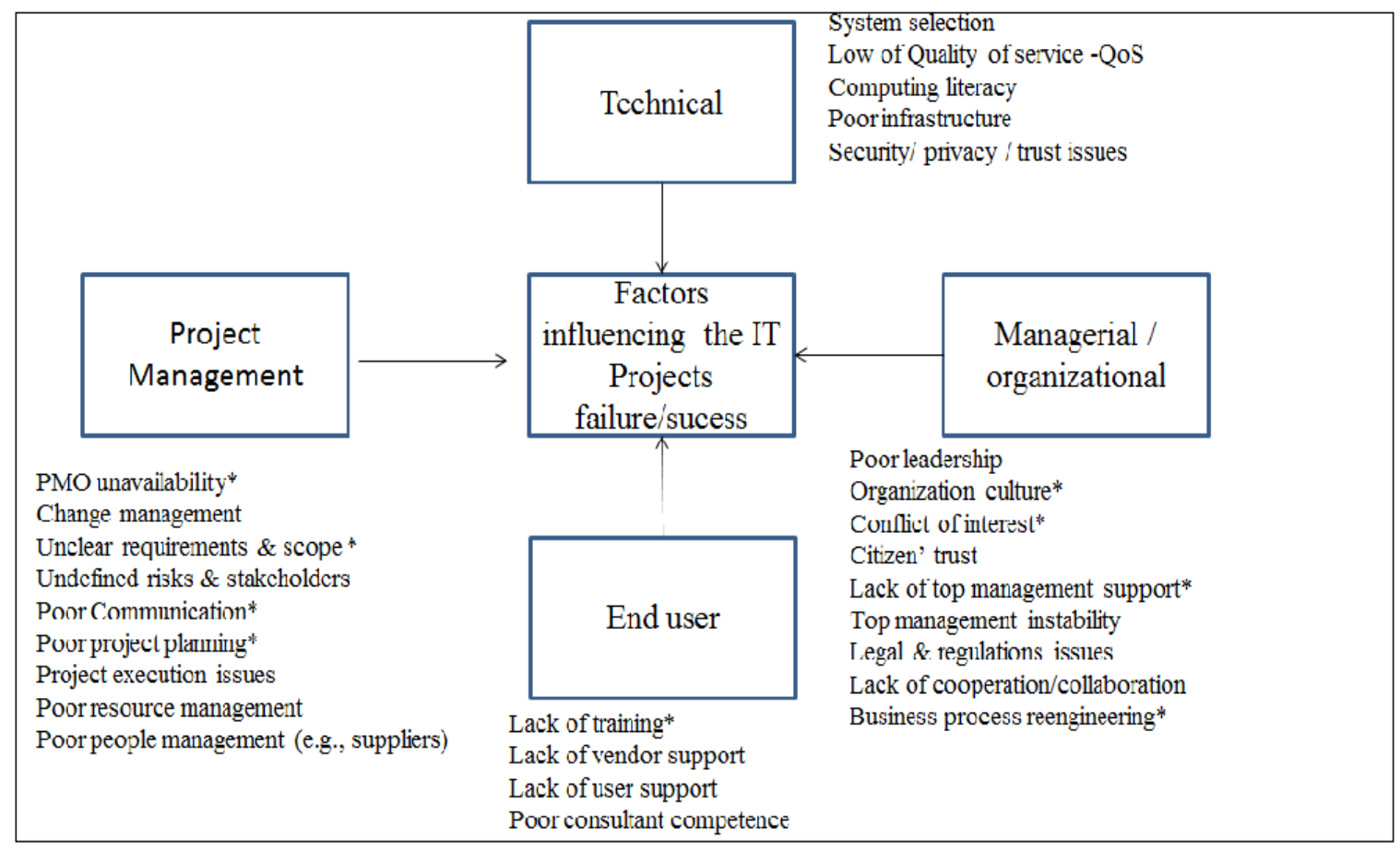

Fig. 1. Classification of factors based on three main perspectives.

From Fig. 1, the most influential factors are located under the management/organizational and PM perspectives. Those marked with an asterisk were mentioned in more than one study, which usually means they are more important. It is noteworthy that all the factors with asterisks belong to the managerial/organizational and PM groups except the training, which belongs to the end-user perspective. The following are general comments about the important factors:

- It makes sense that the early stage in managing a software project is particularly important. This stage guides the execution of the entire project because it is responsible for maintaining a workable plan to ensure that the project addresses the organization's needs. Therefore, when the early stage works out for the best, problems such as unclear objectives, unclear requirements, poor planning, undefined risks, and undefined stakeholders (all listed under the PM group in Figure 1) can be expected to disappear.

- Organizational culture plays a vital role in the success or failure not only in SA but also in other Middle Eastern countries. Even in fully industrialized countries such as the US, the organizational culture is a prime reason for some failures, such as the well-known failure of the FBI VCF management system [10].

- From the end-user point of view, vendor support is critical in avoiding failures. From our experience, the reason might be that IT software projects in SA and in the other Gulf states currently depend largely on commercial products rather than on systems developed in-house. This is true in the public sector.

- All the factors listed in the PM group belong to one or more of the nine PM knowledge areas: integration, scope, time, cost, quality, human resource, communication, risk, and procurement management [30].

- Costs (or budget) have no clear direct impact on failure. This fact confirms the results of some previous studies that showed the low influence of cost in the success or failure of projects in SA. We expected that result because of the huge influence SA governmental financial support has in the IT sector. The problem in SA, however, lies with the business environment, which still 
suffers from many managerial and organizational issues. Like other developing countries, the business environment in SA is characterized by centralization and autocratic leadership. Consequently, BPR as shown in Figure 1, affected the software projects in SA. A disturbing fact about SA is that poor management occurs not only in the IT field but also in other fields such as construction projects [31]. In the near future, the negative impact of this problem is expected to diminish, especially in the public sector because Saudi organizations have recently been required to establish PMOs to raise efficiency and improve project delivery [26]. In turn, that has implications for decreasing the failure rates. According to Altahtooh and Emsley [26], the initial results of forming PMOs in SA and other developing countries indicated that this concept is still at an immature stage compared with developed countries.

- Our findings were confirmed by the past and current literature not only in SA but also in other countries. In general, management/leadership skills and organization culture were cited by [13][17], [20], [24], [26], [29],[32] as an important success criterion in IT projects.

\section{Conclusion and Future Work}

Many organizations around the world suffer from the high rate of software projects failure. There has been a number of studies conducted to address this issue in Saudi Arabia (SA), a developing country. However, there has been lack in evaluation of these studies. This paper has tried to fill this gap by carrying out a property-based critical literature survey aims at identify the factors affecting the software project failures in SA. Main factors have been found to be more human related than technical or financial factors. In particular, lack of top management support, organization culture, business process reengineering, lack of training, and unavailability of PMO. The technical and financial factors however have low influence because of the strong financial capabilities in total. The paper is important for software engineering community in the developing countries. We found that despite all the studies discussed the high failure rate of software projects in SA, no study presented any real world case. For this, we are planning to present a real-world failure case in SA. In addition, we are planning to perform a wide survey on public and private organizations in SA regarding factors leading to failure. The results of both studies (i.e., survey and a realworld failure case; which are going on) would be compared among the results coming up here and in the other studies.

\section{References}

[1] Lehtinen, T., Mäntylä, M., Vanhanen, J., \& Itkonen, J. (2014). Perceived causes of software project failures - An analysis of their relationships. Information and Software Technology, 56(6), 623-643

[2] Dwivedi, Y. K., Wastell, D. G., Laumer, S., \& Henriksen, H. Z., Myers, M. D., Bunker, D., Elbanna, A., Ravishankar, M. N., \& Srivastava, S. C. (2015). Research on information systems failures and successes: Status update and future directions. Information Systems Frontiers, 17(1), 143-157

[3] Remenyi, D. (1999). Stop IT Project Failures Through Risk Management. Routledge, UK

[4] CIO Staff. (2007) When bad things happen to good projects. Retrieved April 2, 2004, from: http://www.cio.com/article/2439385/project-management/when-bad-things-happen-to-goodprojects.html

[5] Hirsch, J. (2014). Toyota recalls 1.9 million Prius hybrids to fix software problem. Retrieved February 12, 2014, from: http://articles.latimes.com/2014/feb/12/autos/la-fi-hy-toyota-prius-recall-20140212

[6] Abouzahra, M. (2011). Causes of failure in healthcare IS/IT projects. The $3^{\text {rd }}$ Int'l Conf. on Advanced Management Science, 4-6 Nov, 2011, Kuala Lumpur, Malaysia

[7] Glass, R. L. (1999). Evolving a new theory of project success. Communications of ACM, 42(11), 17-19 
[8] Lemon, W. F., Liebowitz, J., Burn, J., \& Hackney, R. (2002). Information systems project failure: A comparative study of two countries. Journal of Global Information Management, 10(2), 28-39

[9] Coakes, E., Amar, A. D., \& Granados, M. L. (2015). Success or failure in knowledge management systems: A universal issue. Grand Successes and Failures in IT. Public and Private Sectors - IFIP WG 8.6 Int'l Working Conf. on Transfer and Diffusion of IT.

[10] Afzal, M. H. (2014). Large scale IT projects: study and analysis of failures and winning factors. IETE Technical Report, 31(3), 214-219

[11] Maidin, S. S., \& Arshad, N. H. (2010). IT governance practices model in IT project approval and implementation in Malaysian public sector. Proceedings of the Int'l Conf. on Electronics and Information Engineering (ICEIE 2010).

[12] Abu-shanab, E., \& Al-saggar A. (2013). Reasons behind IT project failure: The case of Jordan. Business Strategies and Approaches for Effective Engineering Management, Business Science Reference.

[13] Almajed, A. I., \& Mayhew, P. (2014). An empirical investigation of IT project success in developing countries. Science and Information Conf., London, UK.

[14] Law, M., Stewart, D., Letts, L., Pollock, N., Bosch, J., \& Westmorland, M. (1998). Guidelines for critical review of qualitative studies. McMaster University Occupational Therapy Evidence-Based Practice Research Group.

[15] DeMarco, T. (1982), Controlling Software Projects. Yourdon Press, New York

[16] Wohlin, C., Runeson, P., Host, M., Ohlsson, MC., Regnell, B., \& Wesslen, A. (2012). Experimentation in Software Engineering: An Introduction, Springer-Verlag Berlin Heidelberg

[17] Aldayel, A., Aldayel, M., \& Al-Mudimigh, A. (2011). The critical success factors of ERP implementation in higher education in Saudi Arabia: A case study. Journal of Information Technology \& Economic Development, 2(2), 1-16

[18] Ngai, E., Law, C., \& Wat, F. (2008). Examining the critical success factors in the adoption of enterprise resource planning. Computers in Industry, 59(6), 548-564

[19] Chadhar, M. A., \& Rahmati, N. (2004). Impact of national culture on ERP systems success. Proceedings of the $2^{\text {nd }}$ Australian Undergraduate Students' Computing Conf.

[20] Al-turki, U. M. (2011). An exploratory study of ERP implementation in Saudi Arabia. Production Planning \& Control, 22(4), 403-413

[21] Alfaadel, F., Alawairdhi, M., \& Al-Zyoud, M. (2012). Success and failure of IT projects: a study in Saudi Arabia. Proceedings of the 11th WSEAS Int'l Conf. on Applied Computer and Applied Computational Science.

[22] Al-Sharief, R. (2012). Key challenges of e-government adoption in less developed countries: The case of Saudi Arabia. International Journal of Customer Relationship Marketing and Management, 3(4), 31-39

[23] Alfarraj, O., Alhussain, T., \& Abugabah, A. (2013). Identifying the factors influencing the development of eGovernment in Saudi Arabia: the employment of grounded theory techniques. International Journal of Information and Education Technology, 3(3), 319-324

[24] AlMajed, A. I., \& Mayhew, P. (2013). Chief information officers' perceptions of IT project success factors in Saudi Arabian public organizations: An exploratory study. IADIS International Journal on Computer Science and Information Systems, 8(1), 66-78.

[25] Baltzan, P., \& Phillips, A. (2009). Essentials of Business Driven Information Systems. McGraw-Hill/Irwin

[26] Altahtooh, U. A., \& Emsley, M. W. (2013). An empirical study into the use of a project management office in IT projects in Saudi Arabia. Issues in Information Systems, 14(1), 366-375

[27] Saleh, M. F., Abbad, M., \& Al-Shehri, M. (2013). ERP implementation success factors in Saudi Arabia. International Journal of Computer Science and Security, 7(1), 15-30 
[28] Alateyah, S. A., Crowder, R. M., \& Wills, G. B. (2013). Identified factors affecting the citizen's intention to adopt e-government in Saudi Arabia. World Academy of Science, Engineering and Technology, 80, 904912.

[29] Altahtooh, U. A., \& Emsley, M. W. (2015), IT projects: Classifying risk factors and identifying project outcomes. Journal of Industrial and Intelligent Information, 3(3), 246-252

[30] Schwalbe, K. (2013). Information Technology Project Management, Cengage Learning.

[31] Ikediashi, D. I., Ogunlana, S. O., \& Alotaibi, A. (2014). Analysis of project failure factors for infrastructure projects in Saudi Arabia: A multivariate approach. Journal of Construction in Developing Countries, 19(1), 35-52

[32] Chen, C. C., Law, C. C. H., \& Yang, S. C. (2009) Managing ERP implementation failure: A project management perspective. IEEE Transactions on Engineering Management, 56(1), 157-170.

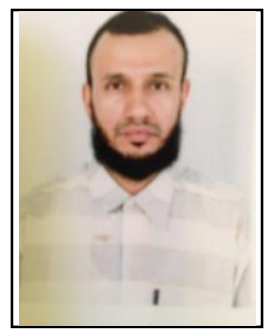

Shouki A. Ebad received his M.S. in computer science from University of Jordan, Jordan, in 2000 and Ph.D. in computer science and engineering from King Fahd University of Petroleum and Minerals, Saudi Arabia, in 2012. Currently, he is working as an assistant professor at the Faculty of Computing \& IT, Northern Border University (NBU) in Saudi Arabia. He also serves as an assistant dean of technical affairs at IT Deanship at NBU. Before that, he held several positions: lecturer, head of information systems department, and vice-dean. He is a sun certified programmer for the Java 2 Platform. His current research interests are search-based software engineering (SBSE), software metrics, software architecture, software project management, and requirements engineering. He published a number of articles in these areas. 